\title{
A Global Investigation of Government and Community Stakeholder Influences on Large Company Engagement in Sustainability
}

\author{
Annette M. Nemetz ${ }^{1}$ \\ ${ }^{1}$ College of Business, George Fox University, Oregon, United States \\ Correspondence: Annette Nemetz, College of Business, George Fox University, Newberg, Oregon, 97132, \\ United States. Tel: 503-320-6625. E-mail: anemetz@georgefox.edu
}

Received: November 10, 2014

Accepted: December 2, 2014

Online Published: January 20, 2015

doi:10.5539/ijbm.v10n2p1

URL: http://dx.doi.org/10.5539/ijbm.v10n2p1

\begin{abstract}
Business organizations are increasingly expected to address sustainability issues and to disclose socially responsible behaviors accurately and transparently, showing that they are effective at managing and being proactive about sustainability challenges. Stakeholder theory was used as a framework to investigate whether influence effects from two institutional stakeholder types were associated with the levels of strategic engagement in sustainability for large publicly listed firms in twenty five countries. Government and community institution effects were quantitatively evaluated as discrete stakeholders with influence on the level of sustainability engagement for firms. Generally, there was significant variation in the average level of company engagement in sustainability, depending on the country. Specific findings on the effects of stakeholder influence showed medium effect sizes and that there were significantly higher levels of strategic company engagement in sustainability when there was an optimal level of national government institutional power and in national communities with positive norms supporting sustainability and citizen-based political action.
\end{abstract}

Keywords: sustainability, business strategy, stakeholder influence, government, community norms, country variation

\section{Introduction}

The acceleration of globalization in recent years has increased the pressures on business organizations for responsible corporate practices, particularly engagement in sustainability efforts. Sustainable practices have been defined as the integration of social, environmental and economic considerations to meet present needs while taking into account the needs of future generations (World Summit, 2005; Brundtland, 1987).

Awareness of sustainability concerns and engagement in sustainable business practices are important strategic topics for business practitioners today. Strategically, there is some recognition that companies that adapt to sustainability challenges are more likely to be successful and able to respond to changes in the competitive business environment caused by resource scarcity, climate change or other adversity (Baldinger \& Nothiger, 2011; Bloomberg, 2013a; KPMG, 2011; Tullis, 2011).

Economic benefits are frequently identified as the positive outcomes of globalization. Loosening of trade barriers, access to new and larger markets, growth and expansion of individual businesses, economic growth across nations, improvements in living standards, and increased flow of ideas and capital yield substantial benefits (Czinkota, Ronkainen, \& Moffett, 2009). Economic growth in many countries has been enhanced by trade, investment capital and labor moving more easily across borders.

The costs of globalization, however, have also been substantial. Shifting labor, compensation, production and capital from one economy to another has led to potential inequalities and substantial economic differences among communities, societies and nations, along with global environmental damage, the lessening of sovereignty in nation-state policy-making and challenging intergovernmental cooperation (Axelrod, Vandeveer, \& Downie, 2011; Feiock, Moon, \& Park, 2008; Green \& Griffith, 2002). As an example, annual environmental costs from global human activity in 2008 were estimated to be US\$ 6.6 trillion, equating to $11 \%$ of global GDP (UNEP, PRI, \& Trucost, 2011). By 2050, environmental externality costs are estimated to be US\$28.6 trillion or $18 \%$ of global GDP (UNEP et al., 2011) and costs accounting for water pollution and water scarcity alone are estimated to reach US\$ 4.7 trillion, or 3\% of global GDP (Baldinger \& Nothiger, 2011). 
Sustainability issues affect all sectors of society, including businesses, governments, non-profit organizations, communities, nations, and individuals. Business organizations, however, contribute substantially to the problems of sustainability. For example, the cost of environmental damage caused by 3,000 of the largest publicly-listed companies across the globe in 2008 was estimated to be US\$ 2.15 trillion, or nearly $33 \%$ of the total environmental externality costs. Five industry sectors--electricity; oil and gas producers; industrial metals and mining; food producers; construction and materials--were identified as responsible for $58 \%$ of the costs (UNEP et al., 2011).

Sustainability issues may be addressed in business organizations through mandatory legal requirements or by voluntary efforts. Mandatory regulatory legal requirements, such as minimum pollution control standards or minimum labor conditions, have been promulgated in many countries to address sustainability issues, however, legal regulations vary substantially by country, and, for some countries exist only marginally (Esty \& Porter, 2005). Internationally, treaty commitments by nations with respect to sustainability issues are typically dependent on voluntary compliance by the individual countries, with national sovereignty usually holding primacy (Axelrod et al., 2011). The distinctions of mandatory compliance are critical because of the variability in actions that business organizations may make in response to government-supported requirements or incentives toward sustainability challenges.

Voluntary sustainability initiatives undertaken by business organizations are typically characterized as falling under the aegis of corporate social responsibility (CSR) that may be defined as "actions that appear to further some social good, beyond the interests of the firm and that which is required by law (McWilliams \& Siegel, 2000, p.117)." Increasingly, business organizations are expected to take into account not only profit-making capabilities in global markets but also to be responsible and transparent about their engagement in social and environmental sustainability concerns (Berman, Wicks, Kotha, \& Jones, 1999; Brammer, Millington, \& Rayton, 2007; Donaldson \& Preston, 1995; Garriga \& Mele, 2004; KPMG, 2011; Tichy, McGill, \& St. Clair, 1997; Woods \& Lodgson, 2002).

With the ascending strategic importance of sustainability for business organizations, there is merit in understanding what may influence a firm to engage in or improve sustainability efforts. Stakeholders have been identified broadly as potential influencers impacting strategic decisions, and, more specifically, as potential influencers of engagement in corporate social responsibility, and may include shareholders, interest groups, customers, employees, environment, suppliers, public interest groups, media and institutionally-based stakeholders, such as governments and communities (Blowfield, 2005; Brammer et al., 2007; Clarkson, 1995; Dimaggio \& Powell, 1991; Doh \& Guay, 2006; Donaldson \& Preston, 1995; R. Freeman, 2010; R. Freeman et al., 2013; R. Freeman, 1984; Frooman \& Murrell, 2005; Frooman, 1999; Hendry, 2005; Turker, 2009; Winn, 2001).

The intent of this study was to empirically investigate whether there was an association between stakeholder influence and company sustainability outcomes by testing the impact of the strength of national government regulatory environments and national community norms regarding sustainability and citizen-based political action. Differences in government and community stakeholder influences by country were hypothesized to impact the levels of engagement in sustainability for large, publicly listed companies.

The theoretical purpose of this study was to contribute further evidence supporting stakeholder theory and to open additional pathways for studying the influence of stakeholders and other influences on corporate social responsibility. Deeper understanding of the factors that influence firm engagement in corporate social responsibility, particularly sustainability initiatives, may prove to be beneficial for practical insights on business practices for stakeholder responsiveness and engagement; for stakeholder influence strategies in corporate engagement; for effective government policy formulation with respect to sustainability; and for the development of community advocacy strategies for sustainability.

\section{Review of Literature}

Empirical studies of corporate social responsibility and/or stakeholder theory have largely focused on the strategic or financial advantages for corporations to engage in socially responsible behavior. Results of financial studies have been mixed, showing positive, negative or limited direct linkages between corporate social responsibility and financial performance (Abbott, Walter \& Monsen, 1979; Alexander \& Buchholz, 1978; Aupperle, Carroll, \& Hatfield, 1985; Berman et al., 1999; Blowfield, 2005; Cochran \& Wood, 1984; Coffey \& Fryxell, 1991; de-los-Ángeles Gil-Estallo, Giner-de-la-Fuente, \& Gríful-Miquela, 2008; Garcia-Castro, Arino, \& Canela, 2010; Griffin \& Mahon, 1997; Hillman \& Keim, 2001; Margolis \& Walsh, 2003; McWilliams \& Siegel, 2000; Peloza, 2009; Post, Preston, \& Sachs, 2002; Roman, Hayibor, \& Agle, 1999; Ullmann, 1985; Waddock \& 
Graves, 1997). Another approach has been to investigate the relationship of corporate social responsibility to corporate performance through strategic factors such as improvements in customer relations, corporate reputation, social impact of product design, and employee satisfaction and retention (Brammer et al., 2007; Gauthier, 2005; Luo \& Bhattacharya, 2006; Murillo \& Lozano, 2006; Puncheva, 2008) and country-specific or variation by country of corporate social responsibility is a third stream of empirical research (Baughn, Bodie, \& Mcintosh, 2007; Gjolberg, 2009; Husted \& Allen, 2006, 2007; Poddi et al., 2009; Turker, 2009; Waldman et al., 2006)

Stakeholder theory has been proposed as an alternative to shareholder-based theories with a core thesis that organizations should be managed in the interest of all stakeholders (R. E. Freeman, 1994; Laplume, Sonpar, \& Litz, 2008). Stakeholders have been defined as individuals, groups or relationships that have an interest in a firm, whether or not the firm has a corresponding interest in the stakeholders, with the presumption that the interests of all stakeholders have intrinsic value (Donaldson \& Preston, 1995; Freeman, 1984; Freeman, 2010; Freeman et al., 2013; Mitchell, Agle, \& Wood, 1997). Stakeholders have been theorized to influence organizations through various strategies and mechanisms such as power availability and influence strategies that may include attempts by stakeholders to gain control over firm resources in an effort to reduce interdependence and uncertainty or taking actions on the firm to meet stakeholder needs (Frooman \& Murrell, 2005; Frooman, 1999; Hendry, 2005; Jawahar \& McLaughlin, 2001; Pfeffer \& Salancik, 1978; Rowley, 1997).

\section{Research Methodology}

The research methodology used in this study is presented in this section. Following a description of the population and sample set, the measures for the variables are described and discussed.

\subsection{Target Population and Sample Set}

The large, publicly listed business firm was the unit of analysis within an empirical setting comprised of a worldwide population obtained from the 2011 Dow Jones Sustainability World Index ("DJSI World"). The companies in DJSI World were characterized as being among the largest firms worldwide based on the Dow Jones Total Global Stock Market Index (Dow Jones \& RobecoSAM, 2012). The top 15\% of the companies in DJSI World were named as sustainability leaders in The Sustainability Yearbook (RobecoSAM, 2012), however, the population for the current study included the entire list of firms in DJSI World, without considering whether a firm was identified as a sustainability leader. Firms in the downloadable DJSI World database were listed with a primary country location, which was used as the company's country of origin for this study, and with a primary industry sector based on the Global Industry Classification System (GICS).

To obtain the sample set, the population data were adjusted to ensure that there was an adequate representative sampling of firms in each country included in the investigation. Countries with at least twenty firms listed in DJSI World remained in the population set, with the firms in the remaining countries eliminated. The final population size from which the sample set was drawn included 2895 firms in twenty-five countries. The twenty-five countries represented the major regions of the world, except for the Middle East (Table 1). Sixteen firms were randomly chosen in each of the twenty-five countries, with the final sample set composed of 400 firms, representing approximately fourteen percent of the adjusted population.

Table 1. Population set drawn from 2011 DJSI world

\begin{tabular}{llll}
\hline Country & Number of Firms & Country & Number of Firms \\
\hline Argentina & 1 & Korea*, Republic of & 199 \\
Australia* & 190 & Kuwait & 5 \\
Austria & 8 & Malaysia* & 38 \\
Bahrain & 1 & Mexico* & 27 \\
Belgium & 15 & Morocco & 5 \\
Brazil* & 91 & Netherlands* & 30 \\
Canada* & 127 & New Zealand & 4 \\
Chile* & 25 & Norway & 16 \\
China* & 144 & Peru & 8 \\
Colombia & 14 & Philippines* & 22 \\
Czech Republic & 3 & Poland & 14 \\
Denmark & 16 & Portugal & 7 \\
Egypt & 3 & Qatar & 5 \\
\hline
\end{tabular}




\begin{tabular}{llll}
\hline Finland & 19 & Russia* & 33 \\
France* & 83 & Singapore* & 32 \\
Germany* & 65 & Slovenia & 64 \\
Greece & 2 & South Africa* & 30 \\
Hungary & 4 & Spain* & 46 \\
India* & 85 & Sweden* & 53 \\
Indonesia* & 29 & Switzerland* & 22 \\
Ireland & 8 & Thailand* & 14 \\
Israel & 6 & Turkey & 3 \\
Italy* & 29 & UAE & 179 \\
Japan* & 317 & United Kingdom* & 935 \\
Jordan & 1 & United States* & 3078 \\
\cline { 2 - 3 } & & Total in DJSI World & 2895 \\
\hline
\end{tabular}

Note. * Countries that met the population adjustment criterion for having at least 20 firms in DJSI World. All other countries were eliminated for a total of twenty five countries in the adjusted population, consisting of 2,895 firms. Sixteen firms were randomly selected in each of the twenty five countries for sample set of 400 firms.

Source: Company and country data obtained Dow Jones, \& RobecoSAM. (2012). Dow Jones sustainability indices: In collaboration with RobecoSAM. Retrieved from http://www.sustainability-indices.com/review/annual-review-2012.jsp

\subsection{Firm Sustainability Measure}

Firm sustainability, the dependent variable, was defined as the measurable outcome of strategic decisions with respect to engaging in sustainability initiatives. Engagement in sustainability was assumed to be the result of both response to relevant legal requirements and any voluntary strategic initiatives of corporate social responsibility that supported sustainable environmental and social practices.

Firm sustainability was measured using 2011 Bloomberg Environmental, Social, and Governance (ESG) disclosure scores. For purposes of this investigation, companies with higher ESG disclosure scores were measured as having higher levels of firm sustainability. For fiscal year 2011, ESG data from Bloomberg were available for 5,217 companies around the world (Bloomberg, 2011). ESG disclosure scores are defined as intangible, extra-financial measures of valuation risk that are based Bloomberg research that "...integrates material company and industry environmental, social and governance key performance indicators, comprehensive and proprietary fundamentals data, and the insight of the wider Bloomberg Industries analyst team... < for $>$ emerging, long-term sustainability themes that present real risks and opportunities for whole industries and individual companies (Bloomberg, 2013a, 2013b)." ESG data are used increasingly by investors to evaluate a company's ESG management and risk exposure (Bloomberg, 2013a; Sustainalytics, 2014).

ESG disclosure scores were chosen for this study as relatively reliable and comprehensive measures for level of firm engagement in sustainability, after considerable research into other possibilities. Of note, measurement of firm sustainability, and corporate social responsibility generally, is difficult and the availability of direct data is limited. Previous empirical studies of corporate social responsibility and/or sustainability have used various methods including reputation indices; individual indicators such as air pollution measures; content analysis of corporate publications; socially responsible certifications such as ISO certifications; sustainability indices such as the Dow Jones Sustainability World Index, the Domini 400 Social Index, and ESG disclosure scores; and sustainability reports based on emergent standards such as the Global Reporting Initiative (GRI) and the United Nations Global Compact (UNGC) methodologies (Baron, Harjoto, \& Jo, 2008; Owen, n.d.; Poddi et al., 2009; Turker, 2009). Many of these data sources have substantial limitations. For example, using data directly from GRI or UNGC reports to measure sustainability performance is limited by the lack of unified social reporting field standards, poor comparability of data across companies, and inconsistency in quality and consistency of company-reported data (Brown, de Jong, \& Levy, 2009; GRI, 2011). As representative of level of firm sustainability, ESG disclosure scores are also limited since they are partially computed from company self-reported data. However, pressures for business organizations to be transparent regarding their sustainability efforts and the granular data that is used to calculate ESG disclosure scores lend weight to the measure. 


\subsection{Stakeholder Influence Measures}

A major assumption of this study was that the decision-making for a company's engagement in sustainability was organizationally situated primarily in the company's country of origin. Some research has suggested that corporate social actions are often oriented toward the locales in which firm headquarters offices are located (Galaskiewicz, 1997; Guthrie, 2003; Kanter, 1997; McElroy \& Siegfried, 1986) and that there is country variation in the practices of corporate social responsibility (Baughn et al., 2007; Galaskiewicz, 1997; Kanter, 1997; McElroy \& Siegfried, 1986; Waldman et al., 2006).

There are potentially many types of stakeholders that may influence a firm. Governments and communities are stakeholders to business organizations that may be particularly relevant for sustainability issues. Both have the capacity to influence through an institutional basis and business organizations may be subject to influence by the institutional settings in which they operate as they seek legitimacy within their environments (Dimaggio \& Powell, 1991; Doh \& Guay, 2006; Tolbert \& Zucker, 1996). Mitchell et al. (1997) argued that stakeholders should meet at least one of three attributes of power, legitimacy and/or urgency. French \& Raven's (2006) model of bases of power was used to evaluate government and community for the sources of power and legitimacy that may exist.

\subsubsection{Government Stakeholder Influence}

Governments are institutions that are based on formal agreements, such as constitutions, laws and policies and have institutional power to influence social entities (Doh \& Guay, 2006; Keim, 2003; North, 1991, 1994). Sustainability actions undertaken by businesses may be based on both legal requirements and/or voluntary efforts. Compliance with laws by a firm, such as meeting pollution control standards or labor condition standards, may depend on the strength of a country's regulatory regime, which vary considerably worldwide (Esty \& Porter, 2005). Doh \& Guay (2006), for example, found that, compared to the United States, Europe's institutional settings had relatively more advanced awareness and support for corporate social responsibility that influenced not only public policy issues but also corporate strategies. Differences in national government institutional regimes may impact not only legal compliance but also expectations about a firm's responsibilities to society.

Governments as formal institutions may seek access to stakeholder influence through formalized legitimacy and coercive power such as promulgating regulatory requirements, or by incentivizing through reward power such as providing subsidies for firms to engage in sustainable practices. Government stakeholder influence was measured as the strength of the regulatory regime that a firm faced in its country of origin, using data from Esty \& Porter's (2005) Environmental Regulatory Regime Index (ERRI). The ERRI was formulated based on factors such as the stringency and sophistication of the regulatory structure, including implementation and enforcement mechanisms; availability of relevant policy-making information; availability of subsidization of natural resources; and the capacity of the environmental institutions (Esty \& Porter, 2005). A higher ERRI indicates a stronger governmental regime. Table 2 shows the ERRI statistics for the countries represented in the sample set.

Table 2. Government stakeholder influence measure: ERRI by country

\begin{tabular}{ll}
\hline Country & ERRI \\
\hline Australia & 1.083 \\
Brazil & -0.077 \\
Canada & 1.297 \\
Chile & 0.177 \\
China & -0.348 \\
France & 1.464 \\
Germany & 1.522 \\
India & -0.759 \\
Indonesia & -0.758 \\
Italy & 0.498 \\
Japan & 1.057 \\
Korea, Republic of & -0.121 \\
Malaysia & -0.127 \\
Mexico & -0.602 \\
Netherlands & 1.747 \\
Philippines & -1.014 \\
\hline
\end{tabular}




\begin{tabular}{ll}
\hline Russia & -0.895 \\
Singapore & 1.771 \\
South Africa & -0.029 \\
Spain & 0.437 \\
Sweden & 1.772 \\
Switzerland & 1.631 \\
Thailand & -0.389 \\
United Kingdom & 1.185 \\
United States & 1.184 \\
\hline
\end{tabular}

Source: Esty, D. C., \& Porter, M. E. (2005). "National environmental performance: An empirical analysis of policy results and determinants." Faculty Scholarshop Series, Paper 430, Table 8, p.418.

\subsubsection{Community Stakeholder Influence}

Firms are embedded in communities as societal and institutional environments and are subject to the expectations and standards of behaviors created through norms (Logsdon \& Yuthas, 1997). Communities are informal institutions based on behavioral norms, culture, beliefs, and/or geographical differences (Doh \& Guay, 2006; Keim, 2003; North, 1991, 1994). Values underlying social and cultural norms provide expectations of behavior socially, politically, and economically. Increasingly, there are pressures that businesses can and should have a significant impact on communities and the socioeconomic well-being of the countries in which they do business (Brammer et al., 2007; Campbell, 2007; Cumming, Bettridge, \& Toyne, 2005; Margolis \& Walsh, 2003) and there are arguments that firms are more likely to pursue broader social benefits beyond profit maximization goals and shareholder value when they feel pressures at the community level (Dimaggio \& Powell, 1991; Doh \& Guay, 2006; Marquis, Glynn, \& Davis, 2007; O’Higgins, 2010; Tolbert \& Zucker, 1996; Wilkes, 2005). Communities may be important influences on corporate social action "...because local understandings, norms, and rules can serve as touchstones for legitimizing corporate social action (Marquis et al., 2007, p. 927)." Communities may seek access to stakeholder influence through referent and coercive power and legitimacy through informal institutional social norms and expectations of social behavior.

Community stakeholder influence was measured using country cultural values with respect to sustainability and the national propensity for citizen-based political action obtained from country-level responses to several questions in the World Values Survey (World Values Survey 1981-2008 Official Aggregate v.20090901, 2009., 2009). A composite score was developed from four questions as representative of national cultural values on sustainability and the propensity for citizen-based political action in each applicable country. Figure 1 is a summary of the calculation method used for the composite score.

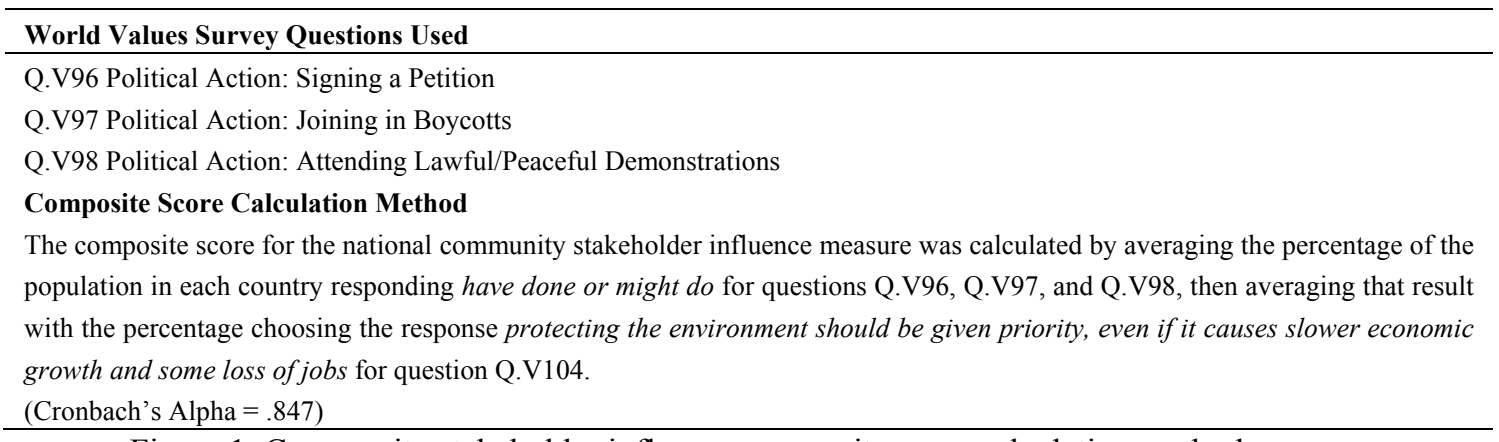

Figure 1. Community stakeholder influence composite score calculation method

Source: World Values Survey 1981-2008 Official Aggregate v.20090901, 2009. World Values Survey Association. Aggregate File Producer: ASEP/JDS, Madrid, http://www.worldvaluessurvey.org/index_surveys

\section{Analysis and Results}

Overall, the results indicated that the hypothesis was supported with medium effect sizes for both government and community stakeholder influences. 


\subsection{Country Variation in Firm Sustainability}

An initial analysis was performed to determine whether there was variation in average levels of company engagement in sustainability, depending on the location of the firm. Results of a one-way ANOVA investigation, illustrated in Figure 2, showed that there were significant differences in firm sustainability when companies were compared by country $(\mathrm{F}(24,375)=5.809, \mathrm{p}<.000)$. On average, companies that tended to have the highest firm sustainability were located in developed economies of several European countries and companies that tended to have the lowest firm sustainability were located in developing economies of several countries in Asia and South America. French firms $(M=49.03)$ had the highest average level of company engagement in sustainability, which was approximately $210 \%$ greater than Malaysian firms $(M=15.84)$, which had the lowest average levels of company engagement in sustainability. Tukey and Games-Howell post-hoc comparisons of the twenty five groups indicated significant differences in firm sustainability between many of the countries. The greatest number of significant pair comparisons were between companies in France and companies in twelve other countries.

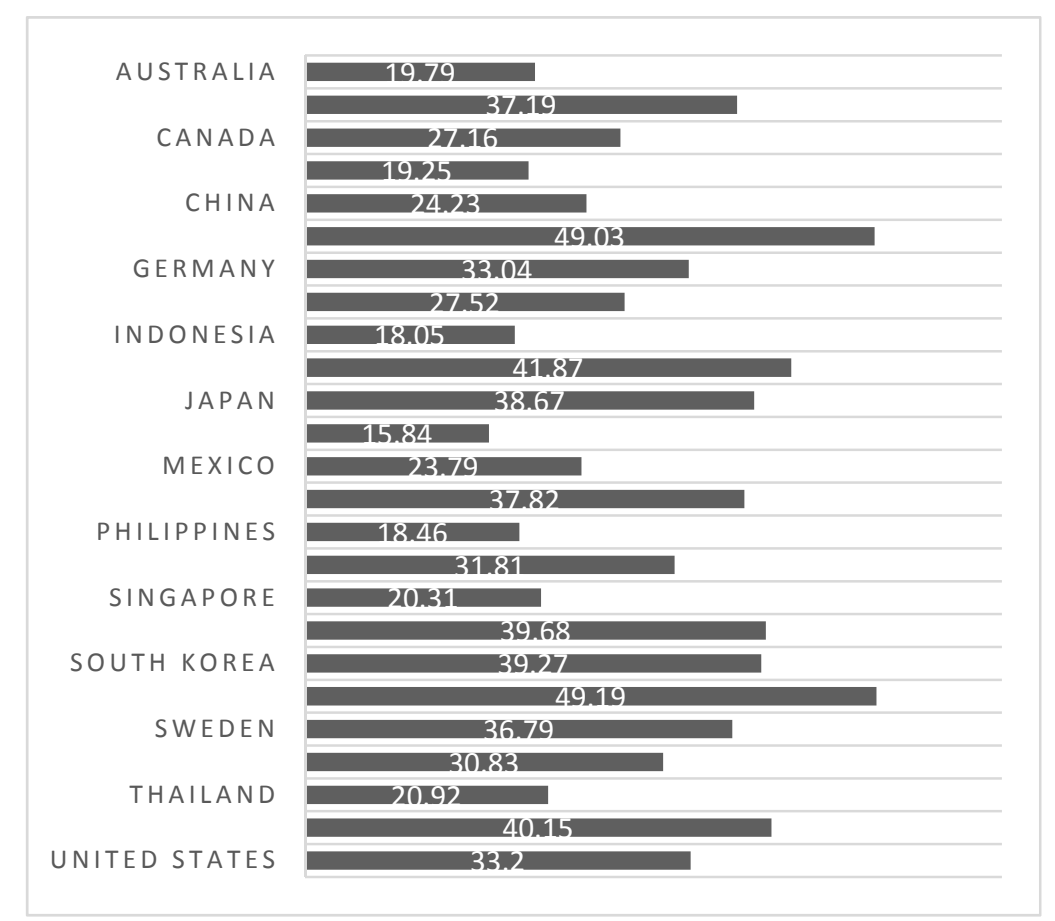

Figure 2. Results of country variation for firm engagement in sustainability

Note. Numbers indicate the average of the ESG disclosure scores for companies studied in that country.

\subsection{Government Stakeholder Influence}

Results from a simple regression analysis indicated that national government stakeholder influence impacted firm sustainability through the strength of a country's governmental institutions, with the tendency of companies located in countries with stronger governmental institutions to have higher levels of sustainability engagement. The results also suggested, however, that there may be an optimal level of government strength for influencing firm sustainability.

The scatter plot shown in Figure 3 indicated that a curvilinear relationship existed between government strength and company engagement in sustainability. Testing for linear and quadratic effects with a multiple regression analysis showed that there was a significant linear effect in the relationship between government stakeholder influence and firm sustainability $\left(\mathrm{B}_{1}=7.67, \mathrm{SE}_{1}=1.618, \beta_{1}=0.385, \mathrm{p}<.000\right)$ and also a significant quadratic effect in the relationship $\left(\mathrm{B}_{2}=-4.219, \mathrm{SE}_{2}=1.426, \beta_{2}=-0.240, \mathrm{p}<.005\right)$. 


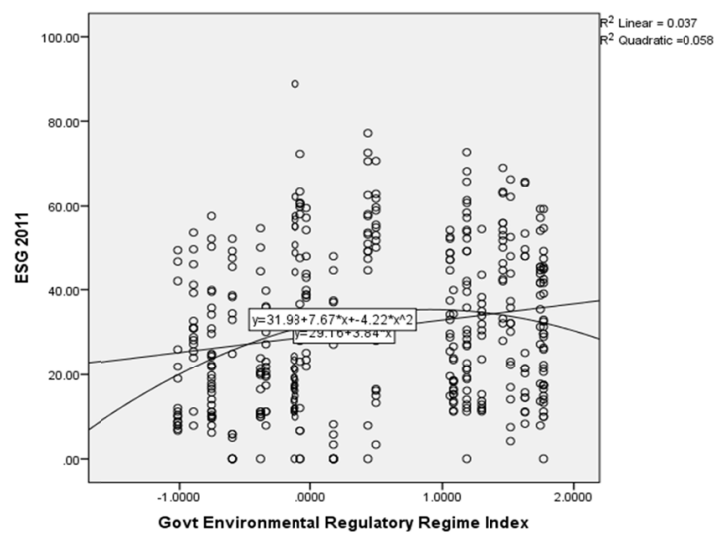

Figure 3. Illustration of curvilinear relationship between government stakeholder influence and firm sustainability

The significant curvilinear results suggested that firm sustainability increases as the strength of government increases, but only to a certain point. The maximum of the curve occurs when the strength of government institutional power as measured by ERRI is equal to $0.91(\mathrm{x}=0.91, \mathrm{y}=38.6)$, indicating the possibility that the optimal level of influence of government is reached at that point. Continuing to increase the strength of government after this point may have diminishing impact on firm sustainability. Overall, there was a positive correlation between national government stakeholder influence and firm sustainability $\left(\mathrm{R}^{2}=.058, \mathrm{~F}(2,397)=\right.$ $12.219, \mathrm{p}<.000$ ), indicating that approximately $6 \%$ of the variation in firm sustainability could be explained by national government stakeholder influence, when not controlling for other factors.

Of note, the mean of the sample set for national government stakeholder influence as measured by ERRI was $0.47(\mathrm{M}=0.47, \mathrm{SD}=0.94)$, indicating that there may be potential opportunities in several of the countries represented in the study for greater government influence on firm sustainability through the strengthening of the regulatory environment as it relates to sustainability.

\subsection{National Community Stakeholder Influence}

A simple regression analysis showed that there was a significant relationship between national community stakeholder influence and firm sustainability $(\mathrm{B}=0.297, \mathrm{SE}=0.076, \beta=0.201, \mathrm{p}<.000)$. The findings suggested that firms with headquarters located in a country with positive supportive norms toward sustainability combined with a propensity for citizen-based political action tended to have higher sustainability engagement. Overall, there was a positive correlation between national community stakeholder influence and firm sustainability $\left(\mathrm{R}^{2}=.041, \mathrm{~F}(1,366)=15.451, \mathrm{p}<.000\right)$, indicating that approximately $4 \%$ of the variation of a company's engagement in sustainability could be explained by national community stakeholder influence, when not controlling for other factors.

\section{Discussion and Recommendations}

Sustainability is currently a high profile topic for businesses, communities and governments. This investigation had goals of providing empirical support for stakeholder theory and for gaining practical insights for business strategy formulation, government policy and community engagement with respect to sustainability. Following is a discussion of the significance and learning regarding the influence factors studied, including thoughts on potential pathways of influence.

Worldwide interest in sustainability has increased on the back of issues such as climate change, unsafe labor conditions, wealth inequity, and social unrest - issues that frequently transcend national borders. This study showed, however, that there was significant variation in sustainability engagement depending on the country in which a firm's headquarters were located. The medium effect sizes of the impact of stakeholder influences showed that the variation in firm engagement in sustainability could be accounted for by country-specific factors such as governmental strength and community societal norms. As institutions with capabilities to influence business firms, government and community were significant factors in firm engagement in sustainability. Of note, however, the medium effect sizes indicate that there is the potential for improvement in the research model by evaluating additional variables such as the level of economic development, GDP, the technological advancement of a country or other factors. 
Businesses are dependent on government for the ability to legally operate the company. Governments have the power to wield influence through several potential pathways. Coercive power of regulations and compliance mechanisms, such as loss of a business license or payment of fines for non-compliance are potential pathways of influence that may lead a firm to increase sustainability efforts for defensive or reputational reasons. Legal compliance is usually considered a minimal level of firm responsibility but a firm may choose to increase sustainability efforts beyond compliance for reasons as varied as increasing competitive advantage, enhancing the firm's reputation, meeting social pressures to go beyond compliance as a show of responsible corporate citizenship, or as a defensive measure to prevent further increases in the regulatory burden by showing the firm's willingness to take on higher levels of social responsibility through voluntary rather than coercive means. Lax regulatory regimes, on the other hand, may influence firms to ignore or disregard compliance with regulation requirements or to place a low value on sustainability needs, possibly leading to minimization of voluntary socially responsible activities that are beyond mission-critical activities.

Government stakeholder influence was measured using ERRI scores that are based on a complex mix of regulatory and institutional criteria (Esty \& Porter, 2005). The measure was useful as a screening mechanism for government stakeholder influence and provided interesting and intriguing results but its complexity does not allow for granular views into the relative importance of regulations compared to subsidies, for example, as key influence factors on firm engagement in sustainability. By using ERRI as a measure, a door has opened for deeper questions on the interplay of the mix of capabilities that governments have at their disposal. Future research dissecting governmental capabilities to study the individual impact of each capability on businesses would potentially provide valuable insights into the relative effectiveness of each as influencers on firm engagement in sustainability. For example, an intriguing research question may be whether the influence on firms is more pronounced using subsidies or through stricter enforcement of regulations. The difficulty will be finding appropriate measures, especially for globally-focused studies.

The results of this study suggested that there may be an optimal level of government strength for influencing firm engagement in sustainability and that increasing government is not necessarily what may be needed. However, the mean ERRI score of the sample set was 0.47 and optimization was reached at ERRI equal to 0.91, indicating that there is potential opportunity for many of the countries studied to increase the effectiveness of government capabilities should greater influence on firm sustainability be desired. Possible actions may include policy improvements in regulatory and compliance standards, increased subsidies for sustainability-related work, or increased private-public partnerships.

Under conditions of strong supportive societal norms for sustainability, firm dependence on the community may be a strong normative pathway of influence that encourages a firm to "do the right thing" with respect to sustainability, including going beyond solely complying with regulations related to sustainability. Businesses depend on communities and societies for approbation, good will, reputation, sales and other business needs.

Societal norms and expectations vary geographically, by country, by region and by local communities and societal norms on a particular topic in combination with citizen-based political action may act as powerful stakeholder influences impacting a firm's behavior, as supported by the results of this study. A higher propensity for citizen-based political action may serve to encourage citizens of the community to actively influence firms to support sustainability. As a practical example, protests and boycotts about labor practices at Nike's contract factories in Indonesia and other countries in the 1990s led to Nike's commitment to improving working conditions in the factories and other initiatives aimed at increasing corporate responsibility in the larger community (Paine, Hsieh, \& Adamsons, 2013). Demonstrations, petitions or boycotts of firms to address a sustainability issue may heighten public awareness of a firm's culpability and escalate negative public perceptions regarding a firm. The desire of a firm to protect its reputation and image may provide communities with a significant pathway of influence.

As a significant indicator for firm sustainability, a country's propensity for citizen-based political action supports the notion that community engagement can make a significant difference in how businesses behave, and, more generally, on important societal issues and concerns. An ability to engage in demonstrations, petitions or boycotts was found to be a useful determinant of how business behavior regarding an important societal issue can be influenced.

Although this research project focused solely on the country in which a firm's headquarters are located, the results are indicators of the importance of understanding the cultural milieu of the countries' in which a firm is doing business. Best practices for global business strategy encourage business managers to develop deep understanding of cultural, political, economic, social and technological factors before market entry into a country 
outside of domestic borders (Czinkota et al., 2009; Daniels, Radebaugh, \& Sullivan, 2011; Deresky, 2008; Peng, 2009; Thomas, 2002). This research supports that view. Because sustainability is a relatively high profile topic in the media that has heightened public awareness through discussions about climate change, human rights and other issues, a firm's due diligence for global strategy should include considerations of local sustainability concerns and issues prior to market entry.

A major assumption and limitation of this study was that the influence of societal norms on a business is most pronounced in the home country or the country in which the firm has its headquarters. Future research investigating the impact of multiple countries in which a firm does business is warranted to develop clearer understanding of the differences in societal pressures that a firm may encounter and that may influence firm sustainability. In addition, delving more deeply into country-specific factors or learning from firms in countries with a tendency toward higher firm sustainability would be a worthwhile research undertaking for the future.

\section{References}

World Summit Outcome. (2005). Resolution adopted by the General Assembly on 16 September 2005 (pp. $1-38)$.

Abbott, W. F., \& Monsen, R. J. (1979). On the measurement of corporate social responsibility: Self-reported disclosures as a method of measuring corporate social involvement. The Academy of Management Journal, 22(3), 501-515. http://dx.doi.org/10.2307/255740

Alexander, G. J., \& Buchholz, R. A. (1978). Corporate social responsibility and stock market performance. Academy of Management Journal, 21(3), 479-486. http://dx.doi.org/10.2307/255728

Aupperle, K. E., Carroll, A. B., \& Hatfield, J. D. (1985). An empirical examination of the relationship between corporate social responsibility and profitability. Academy of Management Journal, 28(2), 446-463. http://dx.doi.org/10.2307/256210

Axelrod, R., Vandeveer, S., \& Downie, D. (2011). The global environment: Institutions, law, and policy. The global environment: Institutions, law, and policy (3rd ed.). Washington, DC: CQ Press.

Baldinger, M., \& Nothiger, M. (2011). The sustainability yearbook 2011 (pp. 1-118).

Baron, D. P., Harjoto, M. A., \& Jo, H. (2008). The economics and politics of corporate social performance (pp. 1-54).

Baughn, C. C., Bodie, N. L., \& Mcintosh, J. C. (2007). Corporate social and environmental responsibility in Asian countries and other geographical regions. Corporate Social Responsibility and Environmental Management, 14, 189-205. http://dx.doi.org/10.1002/csr.160

Berman, S. L., Wicks, A. C., Kotha, S., \& Jones, T. M. (1999). Does stakeholder orientation matter? The relationship between stakeholder management models and firm financial performance. Academy of Management Journal, 42(5), 488-506. http://dx.doi.org/10.2307/256972

Bloomberg, L. P. (2011). The sustainability edge: Sustainability update 2011. Retrieved from http://www.bloomberg.com/bcause/content/themes/sustainability-2014/report/BloombergSustReport2011.p $\mathrm{df}$

Bloomberg, L. P. (2013a). BCAUSE impact report 2013 update. Retrieved from http://www.bloomberg.com/bcause/content/themes/sustainability-2014/report/BloombergSustReport2013.p df\#page $=15$

Bloomberg, L. P. (2013b). Look beyond: Bloomberg for environmental, social, governance data. Bloomberg, L.P. Retrieved from http://www.bloomberg.com

Blowfield, M. (2005). Corporate social responsibility -The failing discipline and why it matters for international relations. International Relations, 19(2), 173-191. http://dx.doi.org/10.1177/0047117805052812

Brammer, S., Millington, A., \& Rayton, B. (2007). The contribution of corporate social responsibility to organizational commitment. International Journal of Human Resource Management, 18(10), 1701-1719. http://dx.doi.org/10.1080/09585190701570866

Brown, H. S., de Jong, M., \& Levy, D. L. (2009). Building institutions based on information disclosure: lessons from GRI's sustainability reporting. Journal of Cleaner Production, 17, 571-580. http://dx.doi.org/10.1016/j.jclepro.2008.12.009 
Brundtland, G. H. (1987). World Commission on Environment and Development. In Our common future. Oxford: Oxford University Press.

Campbell, J. L. (2007). Why would corporations behave in socially responsible ways? An institutional theory of corporate social responsibility. Academy of Management Review, 32(3), 946-967. http://dx.doi.org/10.5465/AMR.2007.25275684

Clarkson, M. B. E. (1995). A stakeholder framework for analyzing and evaluating corporate social performance. The Academy of Management ReviewManagement, 20(1), 92-117.

Cochran, P. L., \& Wood, R. A. (1984). Corporate social responsibility and financial performance. Academy of Management Journal, 27, 42-56. http://dx.doi.org/10.2307/255956

Coffey, B. S., \& Fryxell, G. E. (1991). Institutional ownership of stock and dimensions of corporate social performance: An empirical examination. Journal of Business Ethics, 6, 437-444. http://dx.doi.org/10.1007/BF00382826

Cumming, J. F., Bettridge, N., \& Toyne, P. (2005). Responding to global business critical issues: A source of innovation and transformation for FTSE 350 companies. Corporate Governance: The International Journal of Effective Board Performance, 5(3), 42-51. http://dx.doi.org/10.1108/14720700510604689

Czinkota, M. R., Ronkainen, I. A., \& Moffett, M. H. (2009). Fundamentals of international business. Bronxville, NY: Wessex, Inc.

Daniels, J., Radebaugh, L., \& Sullivan, D. (2011). International business: Environments and operations (13th ed.). Upper Saddle River, NJ: Prentice Hall.

De-los-Ángeles Gil-Estallo, M., Giner-de-la-Fuente, F., \& Gríful-Miquela, C. (2008). Benchmarking corporate social responsibility within Spanish companies. International Advances in Economic Research, 15(2), 207-225. http://dx.doi.org/10.1007/s11294-008-9190-7

Deresky, H. (2008). International management: Managing across borders and culture. Upper Saddle River, NJ: Pearson.

Dimaggio, P. J., \& Powell, W. W. (1991). New institutionalism and organizational analysis. Chicago: University of Chicago Press.

Doh, J. P., \& Guay, T. R. (2006). Corporate social responsibility, public policy, and NGO activism in Europe and the United States: An institutional-stakeholder perspective. Journal of Management Studies, 43(1), 47-73. http://dx.doi.org/10.1111/j.1467-6486.2006.00582.x

Donaldson, T., \& Preston, L. E. (1995). The stakeholder theory of the corporation: Concepts, evidence, and implications. Academy of Management Review, 20(1), 65-91.

Dow, J., \& Robeco, S. A. M. (2012). Dow Jones sustainability indices: In collaboration with RobecoSAM. Retrieved from http://www.sustainability-indices.com/review/annual-review-2012.jsp

Esty, D. C., \& Porter, M. E. (2005). National environmental performance: An empirical analysis of policy results and determinants. Faculty Scholarshop Series, Paper 430.

Feiock, R. C., Moon, M. J., \& Park, H. J. (2008). Is the world "flat" or "spiky"? Rethinking the governance implications of globalization for economic development. Public Administration Review, 68(1), 1-19. http://dx.doi.org/10.1111/j.1540-6210.2007.00832_2.x

Freeman, R. (1984). Strategic management: A stakeholder approach. Boston, MA: Pitman.

Freeman, R. (2010). Managing for stakeholders: Trade-offs or value creation. Journal of Business Ethics, 96, 7-9. http://dx.doi.org/10.1007/s10551-011-0935-5

Freeman, R., Bowie, N., Wicks, A., Werhane, P., Martin, K., Harrison, J., \& Hitt, M. (2013). Managing for stakeholders. Darden Business Publishing, (UVA-E-0383), 1-16.

Freeman, R. E. (1994). The politics of stakeholder theory: Some future directions. Business Ethics Quarterly, 4(4), 409-421. http://dx.doi.org/10.2307/3857340

French, J. R. P., \& Raven, B. (2006). The bases of social power. In J. Pierce \& J. Newstrom (Eds.), Leaders \& the leadership process (4th ed., pp. 146-152). New York, NY: McGraw-Hill.

Frooman, J. (1999). Stakeholder influence strategies. The Academy of Management Review, 24(2), 191-205. 
Frooman, J., \& Murrell, A. J. (2005). Stakeholder influence strategies: The roles of structural and demographic determinants. Business \& Society, 44, 3-31. http://dx.doi.org/10.1177/0007650304273434

Galaskiewicz, J. (1997). An urban grants economy revisited: Corporate charitable contributions in the Twin Cities, 1979-1981, 1987-1989. Administrative Science Quarterly, 42, 445-471. http://dx.doi.org/10.2307/2393734

Garcia-Castro, R., Arino, M., \& Canela, M. (2010). Does social performance really lead to financial performance? Accounting for endogeneity. Journal of Business Ethics, 92(1), 107-126. http://dx.doi.org/10.1007/s10551-009-0143-8

Garriga, E., \& Mele, D. (2004). Corporate social responsibility theories: Mapping the territory. Journal of Business Ethics, 53, 51-71. http://dx.doi.org/10.1023/B:BUSI.0000039399.90587.34

Gauthier, C. (2005). Measuring corporate social and environmental performance: The extended life-cycle assessment. Journal of Business Ethics, 59(1/2), 199-206. http://dx.doi.org/10.1007/s10551-005-3416-x

Gjolberg, M. (2009). Measuring the immeasurable? Constructing an index of CSR practices and CSR performances in 20 countries. Scandinavian Journal of Management, 25(1), 10-22.

Green, D., \& Griffith, M. (2002). Globalization and its discontents. International Affairs, 78(1), 49-68. http://dx.doi.org/10.1111/1468-2346.00238

GRI. (2011). Sustainability Reporting Guidelines, 3(1).

Griffin, J. J., \& Mahon, J. F. (1997). The corporate social performance and corporate financial performance debate. Business \& Society, 36(1), 5-31. http://dx.doi.org/10.1177/000765039703600102

Guthrie, D. (2003). Survey on corporate-community relations. New York: Social Sciences Research Council.

Hendry, J. R. (2005). Stakeholder influence strategies: An empirical exploration. Journal of Business Ethics, 61(1), 79-99. http://dx.doi.org/10.1007/s10551-005-8502-6

Hillman, A. J., \& Keim, G. D. (2001). Shareholder value, stakeholder management, and social issues: What's the bottom line? Strategic Management Journal, 22(2), 125-139. http://dx.doi.org/10.1002/1097-0266(200101)22:2<125::AID-SMJ150>3.0.CO;2-H

Husted, B. W., \& Allen, D. B. (2006). Corporate social responsibility in the multinational enterprise: Strategic and institutional approaches. Journal of International Business Studies, 37(6), 838-847. http://dx.doi.org/10.1057/palgrave.jibs.8400227

Husted, B. W., \& Allen, D. B. (2007). Corporate social strategy in multinational enterprises: Antecedents and value creation. Journal of Business Ethics, 74, 345-361. http://dx.doi.org/10.1007/s10551-007-9511-4

Jawahar, I. M., \& McLaughlin, G. (2001). Toward a descriptive stakeholder theo ry: An organizational life cycle approach. Academy of Management Review, 26(3), 397-414.

Kanter, R. (1997). World class: Thriving local in the global economy. New York: Touchstone Books.

Keim, G. (2003). Nongovernmental organizations and business-government relations: The importance of institutions. In J. P. Doh \& H. Teegen (Eds.), Globalization and NGOs: Transforming business, governments, and society. Westport, CT: Praeger.

KPMG. (2011). KPMG international survey of corporate responsibility reporting 2011. Retrieved from http://www.kpmg.com/Global/en/IssuesAndInsights/ArticlesPublications/corporate-responsibility/Documen ts/2011-survey.pdf

Laplume, A. O., Sonpar, K., \& Litz, R. A. (2008). Stakeholder theory: Reviewing a theory that moves us. Journal of Management, 34, 1152-1189. http://dx.doi.org/10.1177/0149206308324322

Logsdon, J. M., \& Yuthas, K. (1997). Corporate social performance, stakeholder orientation, and organizational moral development. Journal of Business Ethics, 16(12/13), 1213-1226. http://dx.doi.org/10.1023/A:1005741931995

Luo, X., \& Bhattacharya, C. B. (2006). Corporate social responsibility, customer satisfaction, and market value. Journal of Marketing, 70, 1-18. http://dx.doi.org/10.1509/jmkg.70.4.1

Margolis, J. D., \& Walsh, J. P. (2003). Misery loves companies: Rethinking social initiatives by business. Administrative Science Quarterly, 48, 268-305. http://dx.doi.org/10.2307/3556659 
Marquis, C., Glynn, M. A., \& Davis, G. F. (2007). Community isomorphism and corporate social action. Academy of Management Review, 32(3), 925-945. http://dx.doi.org/10.5465/AMR.2007.25275683

McElroy, K. M., \& Siegfried, J. J. (1986). The community influence on corporate contributions. Public Finance Quarterly, 14, 394-414.

McWilliams, A., \& Siegel, D. (2000). Corporate social responsibility and financial performance: Correlation or misspecification? Strategic Management Journal, 21, 603-609. http://dx.doi.org/10.1002/(SICI)1097-0266(200005)21:5<603::AID-SMJ101>3.0.CO;2-3

Mitchell, R. K., Agle, B. R., \& Wood, D. J. (1997). Toward a theory of stakeholder identification and salience: Defining the principle of who and what really counts. Academy of Management Review, 22(4), 853-886.

Murillo, D., \& Lozano, J. M. (2006). SMEs and CSR: An approach to CSR in their own words. Journal of Business Ethics, 67, 227-240. http://dx.doi.org/10.1007/s10551-006-9181-7

North, D. C. (1991). Institutions, institutional change and economic performance. Cambridge: Cambridge University Press.

North, D. C. (1994). Economic performance through time. The American Economic Review, 84, 359-68.

O’Higgins, E. R. E. (2010). Corporations, civil society, and stakeholders: An organizational conceptualization. Journal of Business Ethics, 94(2), 157-176. http://dx.doi.org/10.1007/s10551-009-0254-2

Owen, D. L. (n.d.). Corporate social reporting and stakeholder accountability: The missing link (No. ISSN 1479-5124) (Vol. 44).

Paine, L. S., Hsieh, N., \& Adamsons, L. (2013). Governance and sustainability at Nike. Harvard Business School Publishing.

Peloza, J. (2009). The challenge of measuring financial impacts from investments in corporate social performance. Journal of Management, 35(6), 1518-1541. http://dx.doi.org/10.1177/0149206309335188

Peng, M. (2009). Global strategy (2nd ed.). Mason, OH: South-Western Cengage.

Pfeffer, J., \& Salancik, G. R. (1978). The external control of organizations: A resource dependency perspective. New York, NY: Harper \& Row.

Poddi, L., Vergalli, S., \& Mattei, F. (2009). Does corporate social responsibility affect the performance of firms? In Coalition Theory Network Workshop. Maastricht, The Netherlands.

Post, J. E., Preston, L. E., \& Sachs, S. (2002). Managing the extended enterprise: The new stakeholder view. California Management Review, 45(1), 6-28. http://dx.doi.org/10.2307/41166151

Puncheva, P. (2008). The role of corporate reputation in the stakeholder decision-making process. Business \& Society, 47(3), 272-290. http://dx.doi.org/10.1177/0007650306297946

RobecoSAM. (2012). The sustainability yearbook. Retrieved from http://www.robecosam.com/en/sustainability-insights/library/the-sustainability-yearbook.jsp

Roman, R., Hayibor, S., \& Agle, B. R. (1999). The relationship between social and financial performance. Business \& Society, 38(1), 109-125. http://dx.doi.org/10.1177/000765039903800105

Rowley, T. J. (1997). Moving beyond dyadic ties: A network theory of stakeholder influences. Academy of Management Review, 22(4), 887-910.

Sustainalytics. (2014). Sustainalytics ESG research now available on Bloomberg. Retrieved from http://www.sustainalytics.com/sustainalytics-esg-research-now-available-bloomberg

Thomas, D. C. (2002). Essentials of international management. Thousand Oaks, CA: Sage Publications.

Tichy, N. M., McGill, A. R., \& St. Clair, L. (1997). Corporate Global Citizenship. San Francisco: The New Lexington Press.

Tolbert, P. S., \& Zucker, L. G. (1996). The institutionalization of institutional theory. In S. R. Clegg, C. Hardy, $\&$ W. R. Norde (Eds.), A handbook of organizational studies. London: Sage Publications.

Tullis, P. (2011, March). Bloomberg's push for corporate sustainability: Why Bloomberg broke into the business of measuring other companies' good deeds. Fast Company. Retrieved from http://www.fastcompany.com/1739782/bloombergs-push-corporate-sustainability 
Turker, D. (2009). Measuring corporate social responsibility: A scale development study. Journal of Business Ethics, 85, 411-427. http://dx.doi.org/10.1007/s10551-008-9780-6

Ullmann, A. A. (1985). Data in search of a theory: A critical examination of the relationships among social performance, social disclosure, and economic performance of U.S. firms. Academy of Management Review, 10(3), 540-557.

UNEP, PRI, \& Trucost. (2011). Why environmental externalities matter to institutional investors. Retrieved from http://www.unepfi.org/fileadmin/documents/universal_ownership_full.pdf

Waddock, S. A., \& Graves, S. B. (1997). The corporate social performance - financial peformance link. Strategic Management Journal, $18(4), \quad 303-319$. http://dx.doi.org/10.1002/(SICI)1097-0266(199704)18:4<303::AID-SMJ869>3.0.CO;2-G

Waldman, D. A., Sully de Luque, M., Washburn, N., House, R. J., Adetoun, B., Barrasa, A., ... Wilderom, C. P. M. (2006). Cultural and leadership predictors of corporate social responsibility values of top management: A GLOBE study of 15 countries. Journal of International Business Studies, 37, 823-837. http://dx.doi.org/10.1057/palgrave.jibs. 8400230

Wilkes, V. (2005). Dealing with a global issue: Contributing to poverty alleviation. Corporate Governance-The International Journal of Business in Society, 5(3), 61-69. http://dx.doi.org/10.1108/14720700510604706

Winn, M. (2001). Building stakeholder theory with a decision modeling methodology. Business \& Society, 40(2), 133-166. http://dx.doi.org/10.1177/000765030104000202

Woods, D. J., \& Lodgson, J. M. (2002). Business citizenship: From individuals to organizations. Business Ethics Quarterly, (3), 59-94.

World Values Survey 1981-2008 Official Aggregate. (2009). Madrid. Retrieved from http://www.worldvaluessurvey.org/index_surveys

\section{Copyrights}

Copyright for this article is retained by the author(s), with first publication rights granted to the journal.

This is an open-access article distributed under the terms and conditions of the Creative Commons Attribution license (http://creativecommons.org/licenses/by/3.0/). 